blue-sensitive and records the blue-component image. The intermediate emulsion layer, to which only green and red rays penetrate, is a green-sensitive emulsion, which therefore records the green-component image. The bottom emulsion, to which only red rays penetrate, is red sensitive and similarly records the red-component image.

In processing, which is effected by a series of continuous machines, the treatment is such as to produce in the three layers of the emulsion positive dye images in the so-called 'minus' colours, the gradations of which represent the distribution of the corresponding primary colours in the subject; namely, a yellow (minus-blue) image in the blue-sensitive layer ; a magenta (minus-green) image in the greensensitive layer; and a blue-green (minus-red) image in the red-sensitive layer (Fig. 2). This production of colour images depends on the use of dye-coupling developers (Fischer, 1912), the action of which is to develop exposed silver halide, forming simultaneously in the film a deposit of dye at the same point as the reduced silver. It has been found possible to discover coupler-developers of this kind which give dye images of the required colours and characteristics.
The first stage of processing is normal development and reversal of the silver image. The reversed film is then re-exposed and completely developed in a blue-green coupler-developer, which reduces the remaining silver halide grains and forms corresponding blue-green deposits in all three layers of emulsion. After drying, the film is then treated with a bleaching solution under such conditions that its action affects only the two upper emulsion layers: in these it bleaches the dye and re-forms silver halide, leaving the blue-green colour in the bottom layer. Then follows a third development, with a magenta couplerdeveloper, which forms magenta deposits in the two upper layers. After drying again, the film is given a second bleaching treatment which, however, is allowed only to affect the upper layer, leaving the magenta colour in the middle layer. A fourth development, in yellow coupler-developer, leaves the emulsion with dye images of different colour in each layer. In each layer, however, there is silver com. bined with the dye image and the final treatment is therefore one which removes this silver entirely, leaving the dye images untouched. It is evident that this process lends itself to commercial adaptation to wide fields beyond that of $16 \mathrm{~mm}$. cinematography.

\title{
Main-Line Electrification throughout the World
}

$\mathrm{T}$ a paper on main-line electrification read to the Institution of Electrical Engineers on April 30, E. R. Kaan, a distinguished Austrian engineer, gave a résumé of recent work done in electrifying railways all over the world.

Electric traction on main lines employs nearly always one or other of two systems. The first is the single-phase alternating current system, the voltage with the contact line being usually 15,000 and the frequency $16 \frac{2}{3}$. The other is the direct current system, generally at a voltage of 3,000 , but when overhead equipment is used it is 1,500. Experts agree that all electric traction problems can be solved equally well from the technical and economic points of view whether A.C. or D.C. is employed; which of these two should be employed depends on local conditions.

Switzerland has done more in electrifying railways than any other European country, only a few branch lines still using steam. The new giant locomotives for the Gotthard line are worthy of mention. The double locomotives are rated at 7,500 and 8,800 h.p. respectively, and are the most powerful in Europe. Each is capable of hauling trains weighing 1,400 tons, brought to them on the level track by two locomotives, up the steep Gotthard slope of 1 in 38 at a speed of 50 miles an hour. Each of these double engines has eight driving axles, and the heaviest express trains can be hauled by one locomotive instead of the two necessary with steam traction. Two can pull the heaviest goods trains, for which three steam locomotives are required.

In Germany, by the end of the year, 1,500 miles of the German Railway Co. will be electrified. Although Germany has very extensive coalfields and lignite at her disposal, it is intended to increase the number of electrified lines. National and political economy are the deciding factors; it is necessary to relieve unemployment and provide work for the highly developed German industry. In southern Germany the energy is obtained from water-power stations which are generally State owned. The single phase A.C. system at 15 kilovolts is used by the company, with the exception of the suburban railways in Berlin, which use D.c.

In Sweden, electric traction has been widely adopted. This is due to the abundance of waterpower ; the other conditions usually associated with electrification, namely, heavy traffic, steep gradients and unemployment were absent. The water-power stations are chiefly the property of the State. As most of the lines are level, practically only one kind of locomotive, 80 tons in weight, is employed for all types of trains. There are 268 of these locomotives in service. The very satisfactory results obtained are attributed to the high average speed, the fact that a single man can operate an electric locomotive and the considerably lower costs of maintenance.

In Austria, the electrified lines carry 22 per cent of the entire traffic of the Austrian federal railways. In 1914 the Austrians had studied railway electrification. In 1918 the situation became very difficult as the territories to which she was now restricted possessed only lignite. In 1925 it was decided to electrify the whole of the federal railways, and now a great programme has been proposed, comprising the line Salzburg-Vienna, the southern railway as far as Graz, the eastern railway to the Hungarian frontier and the suburban lines of Vienna.

The Hungarian State Railways use the Kando system of electrification, which differs fundamentally from all other systems. It uses three-phase current, which is the standard system of supply and without converting it applies it directly to the traction motors. The generating station is at Banhida, where the furnaces burn inferior earthy coal raised in the vicinity 
and not worth transporting. This power station and one of the lines from Budapest were financed by an English loan on condition that a considerable part of the supplies were to be procured from English firms.

In Italy, the Valtelina railway was electrified with three-phase current in 1900, and this introduced the three-phase system into upper Italy. When it was decided to electrify the Bologna-Florence railway, direct current was used. Hence two systems, direct current and three-phase, are used in Italy. The bulk of the necessary electrical energy is obtained from water power stations, two thirds of which are railway owned and one third privately owned.

Mr. Kaan said he hoped that the recommendations of the Weir report for the railway electrification of Great Britain will be carried out, and expressed his great admiration for the way in which the Southern Railway Co. has electrified the London suburban lines and the lines to Brighton, Worthing, Seaford and Hastings.
In France it has been decided to use the grid system of the country to supply the railways. A high-tension grid $(60-220 \mathrm{kv}$.) has been constructed to connect the steam power stations of Paris with the water power stations of the Alps and Pyrenees. In order to afford employment, many lines are scheduled for electrification. It is interesting to notice that some of these are situated in the northern districts of the country, which are rich in coal.

In the United States, not quite one per cent of the 262,500 miles of lines have been electrified. The first long distance line was that connecting Baltimore, Washington and Annapolis. The factors that determined the introduction of electric traction were its greater efficiency in meeting competition and the substitution of water-power for coal.

Mr. Kaan also reviewed the position of electric traction in many other countries and in the British Dominions.

\section{The Queen Mary and Timbers of the Empire}

$\mathrm{T}$ HE latest addition to the Cunard fleet, and one of the largest ships now afloat, the Queen Mary, may be truly said to be an Empire ship. The decorations of her interior are largely of wood drawn from the forests of many parts of the Empire-India, the great Dominions and many Colonies.

Teak has long been used in ship construction, and some 1,000 tons of this fine timber has been utilised for decks and gangways, window frames and handrails and so forth. More interesting, perhaps, are some of the timbers which have been used in the magnificent panelling which forms so marked a feature of the interior fittings of the great saloons, smoking-rooms, lounges, corridors and state-rooms.

The builders, Messrs. John Brown and Co., Ltd., and their advisers have ransacked the Empire and indeed the world to collect examples of some of the richest timbers so far known to the trade; though this by no means indicates that the trades are yet aequainted with a tithe of the beautiful timbers existing in the moist tropical and mixed deciduous forests of the world. Apart from teak, the following woods amongst others have been used: laurel wood (Terminalia tomentosa), India; mahogany (Swietenia), British Honduras; cedar mahogany (Guarea cedrata or Thompsonii), Nigeria and Gold Coast; pommele mahogany (Entandrophragma?), Nigeria; Sapele (Entandrophragma cylindricum), British and French West Africa; lemon wood (Xymalos monospora), Southern Rhodesia and South Africa (or, Calycophyllum candidissum, Cuba); tiger oak, said to be Machaerium Schomburghii, Guianas ; Macassar ebony (Diospyros macassar and Diospyros sp.), Celebes; Amboyna (Pterocarpus sp.), Moluccas; Makoré (Mimusops Heckeli) and Avodiré (Turreanthus africana), Ivory Coast; Satinee, or Satiné rubane and Satiné rouge (Brosimum paraense), French Guiana (or, Satiné jaune, Zanthoxylum flavum, French West Indies); Peroba (Aspidosperma polyneuron or Paratecoma peroba, syn. Tecoma peroba), Brazil; oak nut, possibly nut oak (Macadamia ternifolia) and Australian walnut (Endiandra palmerstonii), Australia; Oregon myrtle (Acer macro- phyllum), United States of America; Masur birch (Betula), figured birch from Finland, North Russia and elsewhere; grey maple, stained maple and sycamore (Acer), and olive ash, figured wood (Fraxinus excelsior); walnut (Juglans regia) and beech (Fagus sylvatica), England and Europe. Also Queensland maple and Canadian (dark) birch.

A study of this great ship would be an education. in the products of the forests of the world. The following information kindly furnished by the builders would appear worthy of record on the actual utilisation of some of the above mentioned timbers.

First Class restaurant: Peroba, with feature panels in selected maple burr and Masur birch. Port. side aft private saloon, maple burr ; starboardside aft private saloon, bleached pommele, feature panel in selected maple burr. Tourist dining saloon, ash burr and grey blistered maple- sideboard, walnut. Forward and aft subsidiary stair and aft corridor promenade deck, figured ash with pillar casings and dado and doors elm burr. Midship entrance promensde deck, figured bleached mahogany with dado and doors in pommele. Two writing rooms, promenade deck, oaknut, chestnut and tables ash burr and traight grained ash and pear. Main hall and promenade deck, same timbers as writing rooms with, in addition, teak. First Class library-a beautiful roompromenade deck, oak burr and sycamore with feature panels in oak burr. Observation lounge and cockteil bar, promenade deck, maple burr with dado and horizontal bandings in cedarmah; counter front and jardinières to niche features in finely figured macassar ebony. Corridors, main hall to cocktail bar, prom. enade deck, maple burr with elm burr dado and doors. First Class children's play room, lemonwood. Sun deck, aft entrance, top and bottom course of walls in straight grained chestnut; centre course and doors in root ash; horizontal bandings in chestnut. Sun deck, forward entrance and sports deck entrance, satinee with doors and dado in elm burr. Long gallery, Betula and maple. Starboard gallery, in specially selected laurelwood. First Class smoke room-another very beautiful room-English oak 